BMC JOURNAL OF SCIENTIFIC RESEARCH A Multidisciplinary Peer Reviewed Research Journal ISSN: 2594-3421 (Print), 2773-8191 (Online)

\title{
Buddhist Pragmatism or Pragmatic Buddhism: What is the relationship between Buddhism and Pragmatism?
}

\author{
Shurendra Ghimire* \\ ghimireshurendra@gmail.com
}

Received: Aug. 25, 2021, Accepted: Dec. 15, 2021

\begin{abstract}
With the rise of modernity, the Western world fell into a deep spiritual crisis which forced Comte to Dewey, and Einstein to Whitehead to synthesize a cosmic or humanistic religion. Similarly, the rise of modern science increased western interest in Eastern religions. Because of the ontological resemblance, they further enquired to Buddhism by assuming that would be a religion of their ideal. They began interpreting Buddhism through the lenses of modern philosophies. As a result, Buddhism appeared so diverse that sometimes its positioning is confusing and ambivalent- e.g. 'ethical idealism', 'atheism', 'empiricism', etc. As an attempt of resolving the contradictory positioning, both the original nikayas translated in English by PTS and commentary texts of Buddhism authored by both eastern and western scholars were carefully reviewed. These texts suggested that Buddhism is mostly close to 'ethical pragmatism. To present this closeness, the article at the first describes the cardinal principles of pragmatism, which are- multiple truths, verification of truths, changeability of truth; and then discusses how these principles are embedded in the teaching of Buddha. It also claims that Buddha's efforts on developing new doctrine, constituting a Sangha, practicing sainthood, and defending against rival doctrines and organizations were just strategies of social reform via cultivating ethics rather than the objectives in themselves. This knowledge contributes to the understanding of both pragmatism and Buddhism from each other's perspectives, and at the same time, draws its educational implication in developing critical thinking, and ethical values.
\end{abstract}

Key words: Buddhism, Ethics, Karmic theory, Pragmatism

\section{Introduction}

The teaching of Sakyamuni Buddha was organized as Dharma-Vinaya by his disciples after his death. With the rise of modernity, the Westerners' interest increased toward Eastern religions. They rephrased Dharma-Vinaya as 'Buddhism' in the $18^{\text {th }}$ century. Since the term, Dharma and Buddhism are found interchangeably used in literature to signify the teaching of Buddha. Buddhism has been interpreted hermeneutically and allies with almost major disciplines- cosmology, psychology, religion, philosophy, science, and the Buddha symbolized as peace, non-violence, nirvana, dependent coarising, and timelessness, ethical leader, social reformer.

Scholars view Buddhism with the lenses of modern philosophies and portrait diversely-

\footnotetext{
* Dr.. Ghimre is Assistant Professor in Education at Birendra Multiple Campus (Tribhuvan University)
} 
'ethical idealism' by Radhakrishnan (1989, p. 342); 'empiricism' by Kalupahana (1969, pp. 65- 67) and Pannaloka (2009, p.1); 'atheism' by Hayes, (1988, p. 6); 'social ethics' by Rhys Davids, Universal 'Maitri' and 'ahimsa' by Max Muller, 'social reformer' by Dr. Phramahachanya Khongchinda (1993, p. 218); 'rationalism' by Hoffman (2002, p. 99) and Narada (1988, p. 57); 'Buddhism as a rationalist-atheistic, anti-Brahmanical, anti-caste and egalitarian religion' by Max Weber (2001, p.1); 'a realistic view of life' by W Rahula (1974, p. 17); 'pessimism' by Schopenhauer (Wicks, 2008, p. 137); 'nihilistic' by Nietzsche (Russell, 1945, p.765), etc. Buddhism has been labeled as 'ethical idealism' by the prominent Indian philosopher Radhakrishnan, and, at the same time, allied to egalitarian, social welfare, atheistic, and anti-caste ideologies by Ambedkar. The complex and controversial positioning for Buddhism such as appearing the same thing as both idealism and atheism', and idealism working for social welfare (Lief, 2018), pushed me to engage in Buddhist texts to get first-hand knowledge to identify the relation of Buddhism to modern philosophies. I went to Buddhist nikayas translated by PTS as far as possible and at the same time, tried to find the interface between the interpretation of eastern and western Buddhislogists to understand the Buddhist metaphysics and its social implications.

I applied the 'textual analysis' method (Frey, Botan, \& Kreps, 1999) under the qualitative approach. By analyzing Buddhism with the lenses of modern philosophies as other prominent scholars did, found an adequate resemblance between the teaching of Shakyamuni and lectures of William James, the explainers of pragmatism. The teaching of Buddha seems like a guideline for cultivating morality, compassion, and empathy, and that resembles Dewey's approach of progressive school cultivating democratic culture. Hence, this study arrives at labeling Buddhism as 'ethical pragmatism'. This knowledge contributes to the understanding of both pragmatism and Buddhism, and at the same time, draws its educational implication in developing critical thinking, and ethical values.

\section{Research Methodology}

As the research engages to find new knowledge, this study was engaged to seek what metaphysics was suggested by Buddha and what is its ethical implication to human beings. What the Buddha had said, preached, and applied in his life are the sources of information to synthesize the answer to these questions. The language of communication Buddha used was Pali, since it is assumed that the Pali nikayas are the most authentic source of the teaching of Buddha. Therefore, these texts translated especially by Pali Text Society were studied. In addition, interpretations of the texts by the Buddhist scholars of both East and West for the same opinion as far as possible are added. But, the texts were purposively selected. Texts were analyzed to draw out the meaning from textual analysis method and these historical texts were reinterpreted like hermeneutics interpretation as suggested by Byrne (2001).

In the process of drawing meanings from Buddhist texts other philosophies as mentioned 
above-. 'ethical idealism', 'empiricism', 'atheism', 'social ethics', Universal 'Maitri' and 'ahimsa', 'social reformer', 'rationalism', 'rationalist-atheistic', anti-Brahmanical, anti-caste and egalitarian religion' 'a realistic view of life' 'pessimism' 'nihilistic'; and other realism, pragmatism, Marxism were compared vis-a-vis. This comparison suggested that Buddhism is closest to pragmatism for its ontology of impermanence and goal of cultivating ethical values. This ontology and axiology or 'Dharma-Vinaya' of Buddhism possesses the characteristics of ethical pragmatism. To substantiate, the argument, selective but interfacing excerpts from pragmatism and Buddhism have been presented. With these pieces of information, ideas and arguments are constructed as bricolage. Since, this article, as per the categorization of Kosterec (2016), features a conceptual analysis rather than an empirical study.

The article begins by depicting the resemblance between the basic premises of pragmatism and the teaching of Buddha. In the second part, the discussion concentrates to make an argument of all the teaching of Buddha focusing on ethics- moral standards, ways, and motivation of cultivating morality. Both concepts are synthesized to label Buddhism as 'ethical pragmatism' at the end. The argument stands on historical religious texts since it bears intrinsic limitations. Thus, that is not claimed as final and stable, but something that is continuously open to new insight and interpretation as opined by Henriksson \& Friesen (2012). In this sense, the knowledge claim in this article is guided by the interpretive-constructivist paradigm.

As a conceptual article, the information dispersed in different texts has been processed into a bricolage, in order to develop themes. There are two sections of themes one is setting the basic premises of pragmatism and another is fitting ideas of Buddhist texts into the premises.

\section{Basic premises of pragmatism}

Peirce coined the word pragmaticism/pragmatism from the Greek word pragma (act or deed) and presented his idea of pragmatism as a rule or method for clarifying ideas and concepts. He pointed out the concept of praxis by stating- "beliefs are really rules for action" (Peirce, Jan.1878). Hence, from the beginning, the term pragmatism holds the concept of praxis. Later, William James (1922) defines the concept of pragmatism as 'radical empiricism':

... empiricism because it is contented to regard its most assured conclusions concerning matters of fact as hypothesis liable to modification in the course of future experience; and I say radical because it ...does not dogmatically affirm monism as something with which all experiences has got to square (pp, vii-viii)

William James in the process of explaining his idea 'Pragmatism: a new name for some old ways of thinking (James, 1922)', credits Pierce for the beginning of the idea of pragmatism and made references to other philosophers such as John Dewey, F. C. S. Schiller, Papini, Blondel, de Sailly, J. Milhaud, Le Roy, Serie. From his explanation, pragmatism is understood as a philosophy that accepts subjective and multiple truths, 
and as a yardstick for categorizing dogmatic and pragmatic theory. A theory that meets the criteria of changeability with empirical data or facts and usability relevant to the field is called pragmatic. For James, (a) truth is multiple: pragmatism is 'radical' because it stood for pluralism against the traditional trend of monism (James, 1922, p. 161); (b) truth as verification: true ideas are those that we can assimilate, validate, corroborate and verify (ibid, p. 201); and (c) truth is useful: truthiness of any idea is assessed with its usability. Since the credo for it is: "it is useful because it is true" or that "it is true because it is useful (ibid, p. 203)". Paragraphs below further discuss each of the criteria.

\section{Multiple truths}

Peirce (Nov. 1877) the originator of pragmatism opines that inquiry begins with doubt and belief and finally ends with the truth. For him, any inquiry is guided with old belief and ends to a new fact, however, this process continuously goes ahead:

...the irritation of doubt causes a struggle to attain a state of belief, and hence begins

an inquiry. Thus, our beliefs guide our desires and shape our actions. The most that can be maintained is, that we seek for a belief that we shall think to be true. But we think each one of our beliefs to be true (pp.4-5).

Truth, for the pragmatist, is never absolute but always provisional, due partly to our fallibility as human beings, as well as the sheer amount of knowledge and understanding that we simply cannot access in one lifetime (Plowright, 2016, p. 22). Pragmatism insists that truth in the singular is only a collective name for truths in the plural, these consisting always of a series of definite events (James, 1909, p. 202). Truth or any idea must be practical in solving problems otherwise it cannot be alive enough ever to have been asserted or questioned or contradicted (ibid, p. 206). Since truth or idea goes into the continuous change as per the contextual practicality. Hence, a stream of new problems emerges, the truth of an idea is developed accordingly as the streams of new solutions or truths. This approach of sequential changeability of truth leads to 'the world as the infinite, changing, growing, and elastic'. As Peirce introduced the idea of 'pragmatism' with the belief of multiple shaping of both actions and truths, in the same line, James (1909, p. 166) opined "we find that our pragmatism, though originally nothing but a method, has forced us to be friendly to the pluralistic view. "For James (1909 b, pp. 225-26), the truth is always a swim in a continuum of uncertainty and of indeterminacy; "the notion I have taken ...through-and-through union of adjacent minima of experience, of the confluence of every passing moment of concretely felt experience with its immediately next neighbors."

James (1892) as an extreme subjectivist equalizes the truth with consciousness and depicted consciousness as a continuous flux: "consciousness, then, does not appear to itself chopped up in bits... It is nothing jointed; it flows. A 'stream' is the metaphor by which it is most naturally described.... the stream of thought, of consciousness, or subjective life". He (James, 1922, p. 257) opines that reality for pragmatism is still in the making, and awaits part of its complexion as continuous flux where every part is 
a mediated connection; and truth as hanging together with its very next neighbors in inextricable interfusion, continuity, contiguity, or concatenation. Since, for pragmatism, the truth is not absolute and immutable, but made in actual real-life events; each person has his/her truth; the truth is based on the stream of experiences that are sequential, a serial course of events; never terminates and becomes final. This view on reality and truth indicates that the universe (both human and material) is open-ended, pluralistic, and in-process.

\section{Verifiability of truth}

Peirce (Nov. 1877) categorizing four ways of fixing belief suggests testing the belief in real-life work. He opines that ideas or concepts cannot be separated from experiences; an idea or thought must be tested by experience to verify or validate (Peirce, 1878, p. 293). James (1907) accepts Peirce as:

...true ideas are those that we can assimilate, validate, corroborate and verify. The truth of an idea is not a stagnant property inherent in it. Truth happens to an idea. It becomes true, is made true by events. Its verity is, in fact, an event, a process: the process namely of its verifying itself, its verification. Its validity is the process of its validation (p. 133).

James (1909, p. 40) opines that metaphysical discussions are so much like fighting with the air they have no practical issue of a sensational kind; and on the other hand, admire, scientific theories, as always terminate to definite percepts. For pragmatists, any idea or theory must be deduced and taken into the laboratory and proven with sensations, and 'empirical verifiability' is the hallmark of truth for any idea or theory. James (1907) says:

The truth of an idea is not a stagnant property inherent in it. Truth happens to an idea. It becomes true, is made true by events. Its verity is, in fact, an event, a process: the process namely of its verifying itself, its verification. Its validity is the process of its validation (p. 133).

This excerpt suggests that any idea or theory is open to both verify and falsification. The events to prove or disprove any idea comes via our experiences. As human beings, we experience the world and make sense of it as best as we can. As our experiences change across subjects, time places the agreement with the idea also changes. Hence, the truth is a matter of changing, and it is verified or falsified with our experiences.

\section{Applicability of truth}

While defining 'truth' concerned primarily with religion and morals, James advocates any doctrine which tends to make people virtuous and happy; if it does so, it is 'true' in the sense in which he uses that word. For him, an idea is 'true' so long as to believe it is profitable to our lives, i. e. 'Truth' is one species of good.... "If the hypothesis of God works satisfactorily in the widest sense of the word, it is true" (James, 1907, p. 299). He wants people to be happy, and if belief in God makes them happy let them believe. 
For James, the truth of any theory depends on its instrumental value; any idea remains true as long as it is valuable to the human being. He said-

Any idea upon which we can ride, so to speak; any idea that will carry us prosperously from any one part of our experience to any other part, linking things satisfactorily, working securely, simplifying, saving labor; is true for just so much, true in so far forth, true instrumentally. This is the 'instrumental' view of truth taught so successfully at Chicago, the view that truth in our ideas means their power to 'work', promulgated so brilliantly at Oxford (p. 58).

Pragmatism assumes that the rule of usefulness is the criterion of the truth. A theory represents truth to some extent. The truthfulness of a theory lies in its applicability or usability or practicality. Beliefs are considered to be true if and only if they are useful and can be practically applied. For James, ". . . the ultimate test for us of what a truth means is the conduct it dictates or inspires, ... it is true because it is useful." James (1909b) adds:

"truth here is a relation, not of our ideas to non-human realities, but of conceptual parts of our experience to sensational parts. Those thoughts are true which guide us to beneficial interaction with sensible particulars as they occur, whether they copy these in advance or not (p. 82)."

\section{Compatibility of Buddhism with pragmatism}

This article revolves around the three cardinal principles of pragmatism to show how these features are embedded in Buddhism. But now it begins with a brief discussion on the resemblance of these two isms in their origination.

\section{Resemblance in origination}

There are some significant similarities between Buddhism and Pragmatism. The first similarity is the origination. Buddha developed his idea, established Sangha, and started inculcating moral rules later it was interpreted and expanded to other disciplines too. Pragmatism too with the promulgation was applied in education as progressivism, and later it expanded to other disciplines and places. Buddha developed his idea or dharma from the jumble of 62 schools (DN: Brahmajaala Sutra), his was not one to make $63^{\text {rd }}$, but a different, originated with the significance of social application, not for metaphysical debate. Pragmatism too was developed in the searching of a more practical/ workable one by the American scholars who were not satisfied with various schools of speculative philosophies (that is indicated with the apologue of squirrel by James). Buddha established a Sangha (an organic society) and taught disciples to get cultivated ethics and get happiness. John Dewey too established a school to inculcate democratic culture in students (Fernandes, Araújo \& Dujo, 2018). The second similarity is the multi-disciplinary interpretation. Buddhism as philosophy (or idea in terms of Pierce) has been made clearer by interpreting it with empirical theories of diverse disciplines such as psychology, politics, science, religion, management, etc. 
Pragmatism too has been interpreted with politics, religion, education, management, etc. The third similarity is the examples they used to justify the need for their ideas. Buddha suggested that metaphysical questions can neither be solved nor the solving of these questions lead to the elimination of delusion (moha) and achievement of enlightenment (bodhi or nibbāna). Buddha used the simile to clarify his idea to monk Mālunkyāputta:

It is as if a person were wounded by an arrow thickly smeared with poison and his friends and companions, his kinsman and relatives brought a doctor to treat him and he should say to the doctor: 'I shall not allow this arrow to be extracted until I know - name and caste of the man who wounded me; whether he was tall or short, he was brown or golden-skinned...'(MN 63: Cūlamālunkya Sutta; Bomhard, 2010, pp. 170-172).

Similar to Buddha, James intended to make philosophy practical against the tradition of 'hair-splitting intellectual debate but no agreement in applying it in solving daily problems' in contemporary philosophies- "theories thus become instruments, not answers to enigmas, in which we can rest (James, 1907, p. 53)", and "pragmatism is the attitude of looking away from first things, principles, 'categories' supposed necessities; and of looking towards last things, fruits, consequences, facts (ibid, p. 55)." His simile is:

(A) live squirrel supposed to be clinging to one side of a tree trunk; while over against the tree's opposite side a human being was imagined to stand. This human witness tries to get sight of the squirrel by moving rapidly round the tree, but no matter how fast he goes, the squirrel moves as fast in the opposite direction, and always keeps the tree between himself and the man, so that never a glimpse of him is caught. The resultant metaphysical problem now is this: does the man go round the squirrel or not (ibid, p. 43)?

\section{Pragmatism embedded in Buddhism}

Any idea or principle or theory explains the truth. The soundness of an idea, pragmatism assumes, depends on its practicality. The idea remains valid as long as it is found useful. The validity of an idea is tested in practice and revised with new experiences rather than holding it dogmatically. Thus any idea is considered tentative, changeable, and contextual. The paragraphs below explain the openness to revision for the practical nature of Buddhism as an idea.

\section{Multiple truths in Buddhism}

Buddha explained that there is no prime cause to begin this universe but all the human and non-human phenomena are 'dependent co-arising/ pratītya-samutpāda' (e.g. SN: Dhammacakkappavattana Sutta). He described the very 'dependent co-arising as dynamic, interdependent, and circular in fashion. He further elaborated on the concept as the whole of existence is relative, conditioned, and interdependent; there can be 
nothing free; physical or mental, as everything is interdependent and relative. The doctrine of non-self /anatta or egolessness suggests the relativity and conditionality of truths, and in another word, continuous change or multiplicity of truth. Buddhism further suggests that the sense-organs that make contact and generate feeling to the external world and hence interpret truth too are co-constructed, conditional, and can be ceased (SN: Paticca-samuppada-vibhanga Sutta). This view of Buddhism indicates that the universe both human consciousness and material form is inter-dependent/coarising, becoming/ never-ending, and pluralistic.

The pratitya-samutpāda, the very beginning of Buddhist ontology has accepted multiple truths: every existence is not independent but conditional. These two concepts were later interpreted by Buddhist scholars as absolute (paramartha Satya) and relative (samvritti Satya) truths. Kalupahana (1991, p. 341) claimed that Buddha himself talked on samvritti Satya (worldly conventions) and the parable of the elephant (in DN: Brahmajala Sutta): 'the conditional truth is like blind persons interpret their truths by touching different parts of an elephant' also indicates that Buddha was aware of the truths of whole and parts. Nevertheless, Nagarjuna is credited for categorizing and interpreting two truths. He explained two kinds of truths as those individuals who practice worldly life ethically can experience the truth for their life experiences is relative (samvritti Satya) and those individuals who are enlightened can realize the absolute truth: "understanding of samvritti ("worldly fruit, laukika artha) and, depending upon that, gaining some knowledge of paramartha ("uttimate fruit," lokuttara artha) could serve as a guide for the attainment of freedom (nirvana) (Kalupahana, 1991, p. 335)." In Buddhism, a practitioner bound with limited perception and conceptions experiences multiple and conditional truths, and an enlightened person realized the truth as a universal flux, becoming and changing. Regarding both truths, Buddhism is against static and monist truths, and since, Buddhism and pragmatism interfaces at this point.

\section{Verified truth in Buddhism}

Buddha's time was a period of self-questioning and self-testing. He followed the path of auto-ethnographic research with the experience of two extremes: comfort and lust at first, and misery and celibacy at later (Narada, 1998, pp. 13-22). From the experiment, he learned- 'healthy body is necessary to pursue wisdom'. Furthermore, he came to propose the idea of 'middle path' that would be a possible tool or workable idea as per his mission to cure social pathology. Since he not only pursued the middle path by giving up the speculative idea- 'extreme asceticism is best' of Upanishadic sages, (asceticism is the core of Upanishads, e.g. Katha Upanishad, I. 2, 1-2) however, that was the most dominant idea of the then time but also proved that experimenting oneself is valuable than following speculative ideas of the another (Gombrich, 2006, p. 5; AN: Kalama Sutta). His achievement of, re-discovering the path by his efforts after being lost into human society, made him ascend to Buddha from Siddharth Gautam.

Buddha advised verifying the practicality of an idea in their reasoning and judgment, 
i.e. contextualization (Bomhard, 2010, pp. 160-162). Buddha said to Brahmins name Kālāmas-

"O Kālāmas, it is right for you to doubt, it is right for you to waver. In a doubtful matter, uncertainty has arisen...." As the wise test gold by burning, cutting, and rubbing it (on a piece of touchstone), so are you to accept my words [only] after examining them and not merely out of regard for me."..."When you know for yourselves- these things are moral, these things are blameless, these things are praised by the wise, these things, when performed and undertaken, lead to wellbeing and happiness, then, indeed, do not reject them (AN: Kalama Sutta).

Buddha said to his disciples that some sages hold the idea of eternalism and follow extreme asceticism, some hold nihilism and follow hedonism; but I hold 'dependent coarising' after experimenting it with the middle path (SN: Mahāvagga \& Sacca Sagyutta). He said- no idea is here just for the sake of holding and practicing but must be practical in bringing happiness. Since you have no compulsion to follow mine, you are free to test and follow yours: "I preach you a Dhamma comparable to a raft for the sake of crossing over and not for the sake of clinging to it..."(MN: Alagaddupama Sutta). Hence, he suggested to others to verify the truth of any idea themselves before holding or following.

James's philosophy in the middle of extreme rationalism to extreme empiricism that emerged amidst from mere subjective abstraction of rationalism and objective truth/fact of empiricism. It believes in the trade-off between idea and action, i.e. praxis. He (James, 1907) said-

Pragmatist clings to facts and concreteness, observes truth at its work in particular cases, and generalizes (p. 68). Rationalism sticks to logic and the empyrean. Empiricism sticks to the external senses. Pragmatism is willing to take anything, to follow either logic or the senses, and to count the humblest and most personal experiences (p. 80).

Buddha taught 'how the validity of an idea is tested'. One of such examples is his analysis of the idea of the Verna system- "if Brahma is permanent, eternal, complete and a not changing thing it should not bear, decay, die, re-born and if it is non-living how can it generated living..., if four Verna were layered as per their birth from Cosmic Purusha, why then Brahmin women get pregnant (DN: Brahmanimantana Sutta)" and hence, proved that the assumption of Verna system was false. As a leader of the campaign of social change, Buddha identified the bungles of two dominant ideas of the then society: (a) priestly superficial religion that fosters discriminatory Vernashram dharma (Warder, 2004, pp. 31-36; Davids, 2000, p. 54), and (b) Jain doctrine that encourages just external purification through self-mortification and eternalism (Narada, 1998, p. 98; Shah, 2006, p. 24), and at the same time, he suggested a practical way of life to follow moral conduct: 'Sangha life for monks and family life for lay practitioner' with different kinds of moral rules for Sangha and family life.

Buddha after realizing the causes of the turmoil of the then society went among the 
people. He used intervention for social transformation. He, as a provocative action researcher, dealt with political and moral theories (Robinson \& Johnson, 1970, p. 25). Buddha, on the one hand, conceived that humans can have knowledge of one's ability and develop right desires for social order (e.g. parable of a queen- " Thus, monks, must you train yourselves, SN 47.20"), and on the other, encouraged to test the validity of the doctrine of the middle path (Kalama Sutta).

\section{The practicality of truth in Buddhism}

"There is nothing more practical than a good theory." James C. Maxwell. The Karmic theory seems the most practical idea to guide the then society. The statecraft was not systematic: the judgment was almost invariably associated with bribery, punishments were extremely cruel and barbarous, economical classes were formed with parity between rich and poor, and politics were guided by immoral anarchism and military war for power and money (Sarao, 2004, pp. 15-16). On the other, religion was not humanitarian: the Shakta tradition of Hindu pristine was practicing animal sacrifices to achieve heavenly joy considering that sin can be washed out with yajna (sacrifices); Upanishadic eternalists were inspiring individual purity rather than their ethical responsibility of structural change; Nihilists were just hedonist, their ethical fearlessness was a danger of social anarchism (MN: Alagaddupama Sutta). Therefore, Buddha realized the necessity of social transformation and began it with self-transformation. Buddha interpreted the Upanishadic Karmic theory to make it more practical after six-year-long effort/pondering to begin a social transformation. He realized that the cause of all the social and individual evils is craving and made 'self-transformation' as his credo. Since, by the elaboration of Karmic theory and direct preaching to all moksa seekers (Rewata, 1999, p. 405) and the rulers, he suggested suppressing their craving for power and property, not to abuse but benefit the people (Harvey, 2000, p. 118). Buddha suggested to follow only a practical theory- search for a beginning in a beginningless past is both useless/meaningless and impractical (Piyadassi, 2012; Tola \& Dragonetti, 2007, p. 714, SN: Nidæna Vagga), and ideas of; 'creator of the universe', 'existence of a Supreme Being', and 'praise and sacrifices to gods as a tool of moksha' etc. are meaningless (DN: Brahmajala Sutta). He proposed a practical theory of life: 'identityless and becoming' and 'flux of psychological and physiological changes, a conflux of mind-body and aggregate of five segments' (SN: Anatta Lakkhana Sutta; Silananda, 1999). Based on this theory, he, at first, explained all the individuals are equal regardless of their birth, and, at second, created an egalitarian world/Sangha.

Buddhist ideas are open to change to make it practical. Sangha was open to all worthy ones, irrespective of caste, class, or rank, since, the members were from diverse backgrounds. To control their behaviors and maintain discipline Pratimokkha (code/rule): nearly 227 for monks and 311 for nuns were developed one by one as per necessity (Thanissaro, 2007, p. 11; Bhalerao, 2008, p. 4). He not only suggested harmonizing the rule and doctrine (theory) as per the need of society, i.e. to establish 
different kinds of Sangha but also encouraged senior Arhant to develop an attitude of flexibility and practicality to test, clarify, rearrange and interpret Dhamma-Vinaya themselves in the absence of Buddha (Narada, 1998, pp. 136\&146). His practices were ethical pragmatism: on the one hand, it follows the contextual truths in the formulation of rules for Sangha, and on the other, the criterion of amendment of an idea was cultivating ethics and bringing happiness (Durbin, 2009, p. 425). His teaching was a means to carry man to safety, peace, happiness, tranquility, the attainment of nirvana (parable of crossing raft: Rahula, 1974, p. 11; MN: Alagaddupama Sutta).

\section{Theory for bringing happiness}

Buddha proposed the Karmic theory which is metaphysical in form and ethical in purpose (in MN: Cula \& Maha Kammavibhanga Sutta). He prescribed a set of behaviors with the explanations of their values and purposes to bring happiness as depicted the relationship between values, purpose, and ethics in modern view (e.g. Malloy, 2003, pp. 60-61). His theory comprises of moral rules for daily lives became the most practical tool for the people who were eager to know the relation of 'works in this life to result in the next life (DN: Samannaphalasutra). 'Karmic theory' could explain: a) cosmogonic hypothesis how the material universe is created by karma (the volitional) of sentient beings, b) existential hypothesis for the varied states and conditions of sentient beings, i.e. why a human is neither a worm nor a Buddha and why worms are different from both Buddha and human, and c) a means of social control in Buddhist societies, why the lay human ought to support the monk and why s/he ought to live a moral life (Deitrick, 2005, pp. 7-9). The theory allowed freedom of the will to make choices and take responsibility based on the causal nexus of mind and body without calling upon an ultimate controlling agency. Theory, on the one hand, assumes "human can restrain, curb and subdue his/her mind by own mind, and thus check and eliminate evil propensities by her/himself", and on the other, recommend revisable rules to harmonize with practice. $\mathrm{He}$, along with defining karma as an intentional act through the body, speech or mind, and that can be controlled by an individual with mental training (Wijesekera, 2008, pp. $4 \& 6)$, encouraged practitioner by saying - "those disciples, who follow my advice and maintain purity in their mind, are closer to me rather than who follow me by holding my hand but their minds are not pure". Buddha, as an omniscient, explained assertively - "all karma, whether good or evil, bears fruit, there is no karma, no matter how small, which is void of fruit (e.g. Jataka No. 390)". Among the tripartite stands- metaphysics, morality, and mysticism, of Upanishads (Ranade, 1924, p. 325), he assumed morality the most worthy to making people individually responsible and moral, and emphasized"whatever truths have been expounded to you study them well; practice, cultivate and develop them so that this holy life may last long and be perpetuated out of compassion for the world, and good and happiness of the many (Bomhard, 2010, p. 144))."

Nobody can claim, whether, the Buddha got nirvana or not, but anyone can argue with evidence that he guided people for individual transformation and social reform. 
The Sangha was the place where individuals used to gather to live happily, cultivate ethics and prepare for eternal happiness. Besides the intrinsic, people with extrinsic motivation too entered into the Sangha: the afflicted people with the five diseases who could not get the attendance of the physician outside the Sangha (MahaVagga I.39); the criminal, thief, jailbreaker, debtor, slave, etc. also joined the order of monks and took shelter in the Sangha (Maha Vagga I.39-49; Theragatha: 84). Sangha, on the one hand, was a courtroom for confession, regret, and amnesty (e.g. Angulimala Sutta), and on the other, a therapy lab for eliminating any negative emotions and cultivating moral values.

The discussion made in the above paragraphs suggests that: (a) Buddha adopted the policy of the methodological 'idea' can be revised as per the need of practice which indents to bring human happiness; and (b) for him, human happiness is the ends and any 'idea' or 'theory' is a means.

James said to pragmatism as 'Pragmatism- a new name for the some old ways of thinking', despite his unmentioned, Buddhism was one of these old ways of thinking. These days, socially engaged aspects of then Buddhism, or modern Buddhist is regarded as Pragmatic Buddhism. Before, naming Pragmatism, Buddha had applied the basic premises of pragmatism; and Buddhism was assimilated to any culture for the merits of the inhabitants either in $1^{\text {st }}$ century China (Whalen, 2013) or in $7^{\text {th }}$ century Tibet (Kapstein, 2002). It suggests that Buddhism possesses this intrinsic nature which was later named pragmatism. Therefore, the teaching of Buddha deserves the designation of Buddhist Pragmatism.

\section{Conclusion}

Attempts to understand the teaching of the Buddha began the aftermath of his death. First, it was tried to preserve the teaching by writing what his disciples recited, at the same time understanding 'what does it mean' was practiced by interpreting the context. Interpretation of Buddhism continued over 2500 years and still going on. However, the interpretation became so diverse that Buddhism has been labeled with different ideas such as atheism to anti-Brahmanism or idealism to materialism. This controversy and confusion pushed me to search what the teaching of Buddha is and its then implication. Therefore, original pali Nikaya translated by PTS and other scholarly interpretations were reviewed. Textual analysis engages to develop themes along with comparing other philosophies. Analysis suggested that Buddhism is closest to pragmatism among modern philosophies. Pragmatism is supposed as a suggestion for developing and redeveloping ideas for practical use rather than a philosophical stand of its own fixed realm, it adopts any revisions in the cost of practicality and usability. Buddhism also adopts any changes in the cost of cultivating human behavior to make people happy personally and socially, and even maintaining a close and intermingling relationships of the Sangha and monks with society and rulers. The ultimate goal or bottom line of any revision for Buddhism is cultivating ethical values. Therefore, regarding this 
hallmark labeling, Buddhism with the perspective of modern philosophy is "ethical pragmatism". However, like other historical researches, understanding of Buddhism is influenced by the availability of the sources, quality of translations, perspectives of interpretations, etc., since the article accepts- tentative truth open to revising.

This paper has revealed two significant facts - The first is related to James and his academic integrity. James has mentioned a half-dozen of philosophers, and their ideas to present 'Pragmatism' as a new name for some old ways of thinking. Despite, many commonalities between Buddhism and pragmatism, James did not credit or mention Buddha. This paper cast light on this historical gaping in scholarly tradition. The second is related to how pragmatism is closest among modern philosophies. Buddha's notion of there is no inner core or single realities but multiple truths- dependent arising is cardinal of pragmatism. Budhha's suggestion 'verifiability of truth' mentions 'Kalama sutta' is another resemblance to pragmatism. Similarly, any theory or idea becomes truth as long as it is practical is Buddha's preaching to the disciple which is akin to the notion of both Pierce and James. This idea of Buddha encourages engaged Buddhismi.e. work with Buddhist notion for the welfare of not only humans but all sentient beings.

Buddha not only suggested a set of moral rules depending on the ontological explanation which purposes to transforming individuals by inculcating values of social welfare, non-violence, compassion, and philanthropy but also established the Sangha and implemented. The educational implication of pragmatism was progressive school practice by Dewey to inculcate democratic culture to the future citizens. Buddhism and pragmatism have educational implications for cultivating good qualities; and these two philsohies can serve each other. The mainstream education can pragmatically adopt the Buddhist way of cultivating morality, and, the pragmatic Buddhism can appraise its efficacy of in developing ethical standards and cultivated morality through Sangha or monasteries.

\section{References}

Bhalerao, D.R. (2008). The message of Lord Buddha. In Sirikanchana P. (Ed). Journal of the World Buddhist University Centre, 5 (1).

Bomhard, A. R. (2010) (Edi. \&Tran.). The Buddha and his teachings. Kuala Lumpur: Buddhist Missionary Society.

Brekke, T. (1997). The early Samgha and the laity. Journal of the International Association of Buddhist Studies, 20(2), 7-32.

Byrne, M. (2001). Hermeneutics as a methodology for textual analysis. AORN Journal, 73(5), 968-970.

Davids, T. W. R. (2000) (Trans. \& Edi.).. Dialogues of the Buddha Vol. I, II, III (from the Pali Digha Nikaya). Delhi: Motilal Banarsidass Publishers Private Limited.

Deitrick, J. (2005). Can American Buddhism Accommodate Karma? Journal of Buddhist Ethics, 12: 19. Papers from the JBE Online conference on Revisioning Karma Available 
at http://blogs.dickinson.edu/buddhistethics/files/2011/01/deitrick01.pdf.

Durbin, P. (2009). Comment on queraltó: genuine pragmatic ethics. Ludus Vitalis, 17(32), 423430.

Fernandes, J. P. M., Araújo, A. F. \& Dujo, A. G. ( 2018). Democracy, intelligence and sound education in the perspective of John Dewey. Educ. Pesqui., São Paulo, 44 (e169625)122. DOI: http://dx.doi.org/10.1590/S1678-463420170916925,

Frey, L. R., Botan, Carl H., \& Kreps, G. L.(1999). Investigating communication: An introduction to research methods. Boston: Allyn \& Bacon.

Ghimire, S. (2013). Pedagogy of Buddhist philosophy with special reference to Gumba education (Ph.D. dissertation). Lumbini Buddhist University, Lumbini.

Gombrich, R. F. (2006). How Buddhism began: the conditioned genesis of the early teachings. Routledge Curzon.

Harvey, P. (2000). An introduction to Buddhist ethics: foundations, values and issues. Cambridge: Cambridge University Press.

Hayes, R. P. (1988). Principled atheism in the Buddhist scholastic tradition. Journal of Indian Philosophy 16, 5-28.

Henriksson, C. \& Friesen, N. (2012). Introduction: hermeneutic phenomenology. In N. Friesen et al. (eds.). Hermeneutic phenomenology in education, 1-14. Sense Publishers.

Hoffman, M. L. (2000). Empathy and moral development. R. from http://catdir.loc. gov/catdir/samples/cam032/99029669.pdf

James, W. (1892). The Stream of Consciousness. Journal of Cosmology, 2011, (14). first published in Psychology, Chapter XI. Retrieved from http://cosmology.com/Consciousness121.

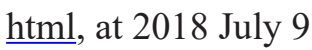

James, W. (1907). Pragmatism and four essays from the meaning of truth. NY: Meridian Books. James, W. (1909). The meaning of truth: a sequel to pragmatism. NY: Longmans, Green, and Co.

James, W. (1909b). A pluralistic universe: Hibbert Lectures at Manchester College on the present situation in philosophy. NY: Longmans, Green, and Co.

James, W. (1912). The will to believe. Longmans, Green, and Co.

James, W. (1922). Pragmatism: a new name for some old ways of thinking popular lectures on philosophy. NY: Longmans, Green and Co.

Kalupahana, D. J. (1969). A Buddhist tract on empiricism. Philosophy East \& West, 19(1), 6567.

Kalupahana, D. J. (1991). Mulamadhyamakakarika of Nagarjuna: the philosophy of the middle way. Delhi: Motilal Banarsidass,Publishers Private Limited.

Kapstein, M. (2002). The Tibetan assimilation of buddhism: conversion, contestation, and memory. ND: Oxford University Press.

Khongchinda, P. (1993). The Buddha's socio-political ideas. R. from http://www.buddhapanya. org.

Kosterec, M. (2016). Methods of conceptual analysis. Filozofia, 71 (3), 220-230. Retrieved from http://www.klemens.sav.sk/fiusav/doc/filozofia/2016/3/220-230.pdf 
Lief, J. (2018). Engaged Buddhism for Social Welfare. The Journal of International Association of Buddhist Universities (JIABU), 11(3), 365-371.

Malloy, D. C. (2003). Understanding the nature of ethics, values, and purposes of business, health care and law: implications and applications for community sport. Paper presented in symposium "The Sport We Want". Retrieved from https://cces. ca/sites/default/files/content/docs/pdf/cces-paper-malloy-e.pdf

Mark, M. W. (2015). Conceptual Paper Outline. DOI: 10.13140/RG.2.1.4962.5768.

Narada, M. (1998). The Buddha and his teachings. Kuala Lumpur: Buddhist Missionary Society.

Nyanaponika, T. \& Bodhi, B. (1970). Anguttara Nikaya: discourses of the Buddha an anthology part I. The Wheel Publication, 155-156.

Pannaloka, W. (2009). Comparative reading into the early Buddhist and Lockean theories of knowledge. R. from https://in.ncu.edu.tw/ ncu7020/Files/Phd_Repord/98/39/thesis. pdf.

Peirce, C. S. (Jan.1878). How to make our ideas clear. Popular Science Monthly, 12, 286-302.

Peirce, C. S. (Nov. 1877). The fixation of belief. Popular Science Monthly 12,1-15.

Piyadassi, T. (2012). The law of cause and effect. Dharma Net.

Plowright, D. (2016). Charles Sanders Peirce: pragmatism and education. Springer

Project Guttenberg, EBook. February, 2004.

Radhakrishnan, S. (1989). Indian philosophy. New Delhi: Oxford University Press.

Rahula, W. (1974). What the Buddha taught. Dharma Net.

Ranade, R. D. (1926). Constructive survey of Upanishadic philosophy. Poona: Oriental Book Agency.

Rewata, D. (1999). Transcendental wisdom and modern knowledge. In Search of Truth: a collection of articles in Honour of $5^{\text {th }}$ Samdong Rimpoche Losang Tenzsin of His Sixtieth Birthday. Varanashi: Alumni of Central Institute of Higher Tibetan Studies Sarnath.

Robinson, H. R. \& Johnson, L. W. (1970). The Buddhist religion. California: Wordsworth Publication Company

Russell, B. (1945). A history of western philosophy. NY: Simonand Schuster,Inc.

Sarao, K. T. S. (2004). Origin and nature of ancient Indian Buddhism. Taipei: The Corporate Body of Buddha Educational Foundation.

Shah, P. K. (2006). Essence of world religions: unity in diversity. Jain Education Series, 911.

Silananda, S. U. (1999). No inner core: an introduction to the doctrine of anatta. Penang: Inward Path Publisher.

Thanissaro, B. (1998). Cula-Malunkyovada Sutta: the shorter instructions to Malunkya MN 63 PTS: $\mathrm{M}$ i 426. https://www.accesstoinsight.org/tipitaka/mn/mn.063.than.html

Thanissaro, B. (2007). The Buddhist monastic code I. R. from http://www.accesstoinsight. org/lib/authors/thanissaro/bmc1.pdf

Thapa, R. (2007). Education in Gumbas, Vihars, and Gurukuls in Nepal: Linking with Mainstream Education. Kathmandu: Centre for Educational Research Innovation and 


\section{Development.}

Tola, F. \& Dragonetti, C. (2007). Buddhism: science, philosophy, religion. Pensamiento, 63 (238), 713-742.

Warder, A. K. (2004). Indian Buddhism. Delhi: Motilal Banarsidass Publishers Private Limited.

Weber, E. (2001). Buddhism: an atheistic and anti-caste religion? In Weber, H. E. (Ed.). Journal of Religious Culture, 50.

Whalen, L. A. I. (2013). Buddhism in China: A Historical Survey. In Encyclopedia of Chinese Philosophy (pp. 29-46). Routledge.

Wicks, R. (2008). Schopenhauer. Oxford: Blackwell Publishing.

Wijesekera, O. H. de A., Jayatilleke, K. N. \& Burtt, E. A. (2008). Knowledge and conduct Buddhist contributions to philosophy and ethics. The Wheel Publication, $50 \mathrm{a} / \mathrm{b}$.

(AN=Anuttara Nikaya, DN= Digha Nikaya, MN=Majjhima Nikaya, SN=Samyutta Nikaya) 